кандидат юридических наук, доцент, доцент кафедры прокурорской деятельности Уральского государственного юридического университета

\section{ПРОБЛЕМЫ ОСПАРИВАНИЯ ПРОКУРОРОМ ДЕЙСТВИЙ (БЕЗДЕЙСТВИЯ) СУДЕБНЫХ ПРИСТАВОВ-ИСПОЛНИТЕЛЕЙ В АДМИНИСТРАТИВНОМ СУДОПРОИЗВОДСТВЕ}

\begin{abstract}
Аннотация:
В статье рассмотрен порядок оспаривания действий должностных лиц Федеральной службы судебных приставов (ФССП) прокуратурой Российской Федерации. Отмечаются проблемы как осуществления прокурорского надзора за исполнением законов судебными приставами, так и обращения прокурора в суд с заявлением об оспаривании действий должностных лиц ФССП. К основным проблемным вопросам отнесены: порядок судебного обжалования действий должностных лиц ФССП по исполнению исполнительного документа, различия в последствиях отказа прокурора от иска в гражданском и административном процессе, срок для подачи исковых заявлений от прокурора. Проведенное исследование позволило определить положительные стороны новелл, внесенных законодателем в правовой статус прокурора, участвующего в административном судопроизводстве, обратить внимание на отдельные недоработки в формулировках процессуального законодательства и предложить возможные пути совершенствования некоторых норм, касающихся проблем оспаривания действий должностных лиц Федеральной службы судебных приставов России.
\end{abstract}

Ключевые слова:

судебный пристав, прокурор, законность, Кодекс административного судопроизводства, оспари вание действий должностных лиц, процессуальный срок.
PhD in Law, Associate Professor, Prosecutorial Activities Department Ural State Law University

\section{CHALLENGING THE ACT (OMISSION) OF BAILIFFS IN THE ADMINISTRATIVE LEGAL PROCEEDINGS BY A PROSECUTOR}

Summary:

This paper describes the procedures to challenge acts and omissions of the officials of Federal Bailiffs Service by Public Prosecution Office of the Russian Federation. The research notes the problems of prosecutor's supervision of law enforcement by bailiffs and recourse of a prosecutor to a court to challenge acts of the officials of Federal Bailiffs Service. The main problematic issues include the procedure for appealing against acts of the officials of Federal Bailiffs Service to comply with court orders, different legal effects of waiving a claim in civil and administrative law, terms of the prosecutor's statement of claim. This study identifies the positive aspects of the legislative innovations concerning the legal status of a prosecutor involved in the administrative legal proceedings. The author shows the gaps in the procedural law and suggests the possible ways of improving the certain standards of challenging the acts of officials of Federal Bailiffs Service in Russia.

Keywords:

bailiff, prosecutor, legitimacy, Code of Administrative Procedure, challenge the acts of the officials, procedural time limits.

Осуществление прокуратурой России надзора за исполнением законов службой судебных приставов является одной из важнейших отраслей надзорной функции органов прокуратуры. Несмотря на многочисленные проблемы, связанные с организацией порядка исполнения судебных решений службой судебных приставов, следует признать, что при этом нет ни одной правовой системы, в которой на практике иностранные судебные решения подлежат автоматическому приведению в исполнение без специальных национальных процедур и (или) особых условий приведения в исполнение (даже если это возможно теоретически) [1]. Наиболее распространенными правонарушениями при осуществлении исполнительных действий следует считать бездействие судебных приставов-исполнителей, несоблюдение сроков возбуждения исполнительных производств, нарушение порядка наложения ареста на имущество должника, прекращение или окончание исполнительного производства без законных на то оснований.

Несмотря на широкий спектр надзорных непроцессуальных правовых средств, выносимых прокурором в отношении судебных приставов, в практической деятельности наиболее частым актом реагирования выступает протест. Указанное обстоятельство связано не только с тем, что любое действие судебных приставов-исполнителей сопровождается вынесением ими постановления, но и с существующей проблемой в процедуре вынесения прокурором представления на 
выявленные правонарушения. Ввиду отсутствия у старшего судебного пристава соответствующего отдела территориального органа Федеральной службы судебных приставов России (далее - ФССП России) полномочий по привлечению к дисциплинарной ответственности подчиненных ему работников прокуроры районного звена вынуждены направлять представления главному судебному приставу субъекта Российской Федерации, что, во-первых, существенно осложняет работу районных прокуратур, которые должны направить проект представления в вышестоящую прокуратуру для согласования и дальнейшего его вынесения в адрес главного судебного пристава субъекта Российской Федерации, а во-вторых, делает представление прокурора достаточно редким актом. Так, по результатам работы за 1-е полугодие в адрес Управления ФССП по Ростовской области поступило 1689 актов реагирования, из которых 19 представлений об устранении нарушений закона и 1670 протестов на противоречащие закону правовые акты [2]. В связи с этим целесообразно внести поправки в ст. 10 федерального закона «О судебных приставах» в части предоставления старшему судебному приставу права на привлечение к дисциплинарной ответственности подчиненных работников, что позволит прокурору района и иной приравненной к прокуратуре субъекта специализированной прокуратуре самостоятельно вносить представления в адрес старшего судебного пристава [3].

Оспаривание действий судебных приставов расценивается прокурором как крайняя мера, используемая прокурором после вынесения им акта прокурорского реагирования. При этом неверно полагать, что прокурор обращается в суд с административным исковым заявлением только после отказа должностных лиц ФССП России в удовлетворении протеста на незаконный правовой акт. Несмотря на отсутствие законодательно регламентированной обязанности исполнить требования протеста, удовлетворяемость последних очень высока и составляет от 90 до 96 \% [4, с. 294]. На практике обращению прокурора в суд с заявлением об оспаривании действий должностных лиц ФССП РФ предшествует, как правило, неисполнение требований представлений, направленных ранее прокурорами областного уровня руководителям территориального органа ФССП России, например в виде непринятия мер по устранению нарушений, отраженных в представлении.

Так, например, решением Ленинского районного суда города Уфы были удовлетворены требования прокурора, заявленные в административном исковом заявлении, и признан фракт бездействия главного судебного пристава по выполнению законных требований прокурора. Судом установлено, что алименты с должника не взыскивались с момента возбуждения исполнительного производства, меры принудительного исполнения не применялись. Заявление в суд было подано прокурором по итогам неисполнения в месячный срок требования представления.

В качестве одной из основных проблем осуществления прокурорского надзора в сфере исполнения судебных актов выступает порядок судебного обжалования действий должностных лиц ФССП РФ по исполнению исполнительного документа. Указанный порядок регламентируется бланкетной нормой ст. 128 федерального закона «Об исполнительном производстве» [5]. Так, если административное дело рассматривается судами общей юрисдикции, то оспаривание действий должностных лиц ФССП России регламентируется ст. 441 Гражданского процессуального кодекса Российской Федерации (далее - ГПК РФ) и ст. 360 Кодекса административного судопроизводства Российской Федерации (далее - КАС РФ), однако осуществляется по правилам гл. 22 КАС РФ [6]. Между тем положения КАС РФ не содержат нововведений и полностью заимствуют нормы ныне утратившей силу гл. 25 ГПК РФ, оставляя при этом ряд неразрешенных проблем.

Так, в соответствии с ч. 4 ст. 218 КАС РФ, в случаях, предусмотренных данным процессуальным кодексом, прокурор в пределах своей компетенции вправе обратиться в суд с административным иском о признании незаконными решений, действий (бездействия) органов, организаций, лиц, наделенных государственными или иными публичными полномочиями, в защиту прав, свобод и законных интересов иных лиц, если полагает, что оспариваемые решения, действия (бездействие) не соответствуют нормативному правовому акту, нарушают права, свободы и законные интересы граждан, организаций, иных лиц, создают препятствия к осуществлению их прав, свобод и реализации законных интересов или на них незаконно возложены какие-либо обязанности. В силу ч. 1 ст. 39 КАС РФ прокурор вправе обратиться в суд с административным исковым заявлением в защиту прав, свобод и законных интересов граждан, неопределенного круга лиц или интересов Российской Федерации, субъектов Российской Федерации, муниципальных образований, а также в других случаях, предусмотренных федеральными законами.

Следует заметить, что традиционно участие прокурора в гражданском процессе осуществляется преимущественно в защиту прав и свобод граждан и неопределенного круга лиц. Так, по итогам 2016 г. 91 \% заявлений прокуроров в суды общей юрисдикции направлен в интересах граждан и неопределенного круга лиц и только $9 \%$ - в интересах Российской Федерации, субъектов Российской Федерации, муниципальных образований. Однако положения КАС РФ свидетель- 
ствуют о смещении вектора защиты с граждан в пользу второй категории лиц: интересов Российской Федерации, субъектов Российской Федерации и муниципальных образований. Положения КАС РФ практически лишают прокурора права обращаться с административным исковым заявлением в защиту интересов граждан. В соответствии со ст. 39 КАС РФ, прокурор вправе подавать административное исковое заявление в интересах гражданина только в случае, если гражданин по состоянию здоровья, возрасту и другим уважительным причинам не может сам обратиться в суд.

В соответствии с ранее действовавшей ч. 1 ст. 252 ГПК РФ, прокурору также не было предоставлено право на обращение в защиту прав и свобод граждан с заявлением об оспаривании решения, действия органа государственной власти, однако положения ч. 1 ст. 45 ГПК РФ, содержащие основания для участия прокурора в гражданском процессе, в том числе в защиту граждан, предусматривали возможность обращения прокурора с заявлением в защиту прав гражданина, если нарушения затрагивали социальные, трудовые правоотношения, защиту семьи, материнства, отцовства и детства, социальную защиту, охрану здоровья, обеспечение прав на благоприятную окружающую среду, образование. Таким образом, в указанных случаях при наличии письменной просьбы гражданина прокурор мог оспаривать незаконные действия (бездействие) судебных приставов-исполнителей. Ограничения, содержащиеся в ныне действующей ст. 39 КАС РФ, с одной стороны, обосновываются принципом свободы волеизъявления граждан на судебную защиту и ограничением защиты прокурором частноправовых интересов в суде. С другой стороны, не позволяют прокурору добиться устранения нарушений в действиях судебных приставовисполнителей в тех случаях, когда представления прокурора остались неисполненными, а значит, невозможно эффрективное осуществление надзора.

Таким образом, продолжает укрепляться тенденция по уменьшению направляемых прокурором заявлений в суды, в том числе арбитражные суды, при общей тенденции к росту количества рассматриваемых судами гражданских дел (в том числе об оспаривании действий должностных лиц ФССП России). Полагаем, что указанное ограничение полномочий прокурора является недопустимым и преждевременным. Смещение акцента в оспаривании прокурором действий (бездействия) судебных приставов в пользу исключительно интересов государства и органов местного самоуправления не только не позволяет защитить интересы граждан, обращающихся за защитой в органы прокуратуры, но и делает осуществление прокурорского надзора неэффрективным, так как ставит возможность дальнейшего реагирования на нарушения в рамках судопроизводства в зависимость от того, чьи интересы нарушаются.

Еще одной проблемой являются существенные различия в последствиях отказа прокурора от иска в гражданском и административном процессе. Частью 5 ст. 39 КАС РФ предусмотрено, что в случае отказа прокурора от административного иска, поданного в защиту прав, свобод и законных интересов неопределенного круга лиц, рассмотрение административного дела по существу продолжается. В ГПК РФ последствия отказа от иска прокурора в защиту неопределенного круга лиц прямо противоположные. В соответствии со ст. 220 ГПК РФ, производство по делу прекращается в случае, если процессуальный истец отказался от иска и отказ принят судом. Зачастую прокурор пользуется правом на отказ от иска в случаях, когда ответчик добровольно исполнил требования прокурора, что также широко распространено в отношении заявлений об оспаривании действий должностных лиц ФССП России. Наконец, в соответствии с п. 12 постановления Пленума Арбитражного суда Российской Федерации от 23 марта 2012 г. № 15 «О некоторых вопросах участия прокурора в арбитражном процессе», отказ истца от иска по делам, предусмотренным абз. 2 и 3 ч. 1 ст. 52 АПК РФ, не препятствует рассмотрению дела [7]. Следовательно, можно заключить о наличии в действующем процессуальном законодательстве существенных различий в порядке регламентирования отказа от иска в защиту неопределенного круга лиц. Представляется необходимым унифицирование указанных норм в целях единства защиты прав участников исполнительного производства, а также прав неопределенного круга лиц.

Наконец, еще одним критерием, влияющим на эффрективность оспаривания прокурором постановлений, действий должностных лиц ФССП России, является срок для подачи административных исковых заявлений, который составляет 10 дней со дня, когда гражданину, организации или иному лицу стало известно о нарушении их прав, свобод и законных интересов. Следует отметить, что указанная норма дублирует ныне утратившую силу ч. 2 ст. 441 ГПК РФ. Однако, как и ранее, на практике представляется, что данный срок очень мал и не позволяет прокурору, осуществляющему надзор за исполнением законов в структурном подразделении ФССП России, оценить, подготовить и предъявить административное исковое заявление. Указанное осложняется еще и тем, что, как утверждалось выше, решение об оспаривании действий судебных приставов не всегда принимается в отношении незаконных правовых актов должностных лиц ФССП России, но также после невыполнения представлений прокурора. В случае же предъявления прокурором указанных исков с одновременным ходатайством о восстановлении пропущенного срока 
суды зачастую отказывают в восстановлении пропущенного срока, расценивая причину его пропуска неуважительной. В связи с этим представляется необходимым увеличить процессуальный срок для обращения прокурора с административным исковым заявлением до тридцати дней.

В заключение следует отметить необходимость серьезного пересмотра полномочий прокурора при обращении с административными исками в суды общей юрисдикции об оспаривании действий судебных приставов-исполнителей, а также процессуальных аспектов участия прокурора в административном судопроизводстве.

\section{Ссылки:}

1. Hill J., Chong A. International Commercial Disputes. Commercial Conflict of Laws in English Courts. $4^{\text {th }}$ ed. Oxford (UK), 2010. P. 4-5.

2. Аналитический отчет о деятельности Управления Федеральной службы судебных приставов по Ростовской области за 1-е полугодие 2016 г. [Электронный ресурc]. URL: http://r61.fssprus.ru/analiticheskijj_otchet_o_dejatelnosti_upravlenija_federalnojj_sluzhby_sudebnykh_pristavov_po_rostovskojj_oblasti_za_1-oe_polugodie_2016_goda/?print=1 (дата обращения: 01.08.2017).

3. О судебных приставах : федер. закон от 21 июля 1997 г. № 118-Ф3 : с изм. от 3 июля 2016 г. // Российская газета. 1997. № 149. 5 авг.

4. Законность: состояние и тенденции в 2010-2014 гг. Деятельность прокуратуры по ее обеспечению : науч. докл. / под общ. ред. О.С. Капинус. М., 2015. 406 с.

5. Об исполнительном производстве : фредер. закон от 2 окт. 2007 г. № 229-Ф3 : с изм. от 3 июля 2016 г. // Российская газета. 2007. № 223. 6 окт.

6. Гражданский процессуальный кодекс Российской Федерации : фредер. закон от 14 нояб. 2002 г. № 138-Ф3 : с изм. от 3 июля 2016 г. // Российская газета. 2002. № 220. 20 нояб. ; Кодекс административного судопроизводства Российской Федерации : федер. закон от 8 марта 2015 г. № 21-Ф3 : с изм. от 30 июля 2017 г. // Там же. 2015. № 49. 11 марта.

7. Арбитражный процессуальный кодекс Российской Федерации : федер. закон от 24 июля 2002 г. № 95-Ф3 : с изм. от 29 июля 2017 г. // Российская газета. 2002. № 137. 27 июля.

\section{References:}

Hill, J \& Chong, A 2010, International Commercial Disputes. Commercial Conflict of Laws in English Courts, $4^{\text {th }}$ ed., Oxford (UK), pp. 4-5.

Kapinus, OS (ed.) 2015, Legality: the state and trends in 2010-2014. The prosecutor's office activities to promote it: a scientific report, Moscow, 406 p., (in Russian). 